\title{
Gallibacterium anatis. An Emerging Pathogen of Poultry Birds and Domiciled Birds
}

Shiv Varan Singh, Bhoj R Singh ${ }^{*}$, Dharmendra K Sinha, Vinodh Kumar OR, Prasanna Vadhana A, Monika Bhardwaj and Sakshi Dubey

Division of Epidemiology, ICAR-Indian Veterinary Research Institute, Izatnagar-243 122, Uttar Pradesh, India

*Corresponding author: Dr. Bhoj R Singh, Acting Head of Division of Epidemiology, ICAR-IVRI, Izatnagar-243122, Uttar Pradesh, India, Tel: +91-8449033222; E-mail: brs1762@ivri.res.in

Rec date: Feb 09, 2016; Acc date: Mar 16, 2016; Pub date: Mar 18, 2016

Copyright: () 2016 Singh SV, et al. This is an open-access article distributed under the terms of the Creative Commons Attribution License, which permits unrestricted use, distribution, and reproduction in any medium, provided the original author and source are credited.

\begin{abstract}
Gallibacterium anatis though known since long as opportunistic pathogen of intensively reared poultry birds has emerged in last few years as multiple drug resistance pathogen causing heavy mortality outbreaks not only in poultry birds but also in other domiciled or domestic birds. Due to its fastidious nature, commensal status and with no pathgnomonic lesions in diseased birds $G$. anatis infection often remains obscure for diagnosis. Poor understanding of its epidemiology, virulence factors and pathogenesis work on development of effective vaccine obscured its importance; however, it is difficult to get rid of $G$. anatis infection on affected poultry farms. The present review summarises the current knowledge on $G$. anatis and its infections.
\end{abstract}

Keywords: Gallibaterium; Pasteurella anatis, Egg drop; Mortality outbreaks; Multiple drug resistance; Vaccine

\section{Introduction}

Global meat production is predicted to rise by $1.6 \%$ over the outlook period, with poultry becoming the largest meat sector by 2020 [1]. Gallibacterium anatis infection is an emerging disease of poultry. Growing concern about $G$. anatis is its poorly understood growth kinetics, virulence markers, pathogenesis and vaccine(s) to control. Gallibacterium anatis (earlier known as Pasteurella anatis) is commensal in upper respiratory tracts and the lower genital tracts of healthy chickens $[2,3]$. It has been reported to be associated with bacteremia, oophoritis, follicle degeneration, salpingitis, peritonitis, hepatitis, enteritis, and respiratory tract diseases in chickens [4-8]. Gallibacterium anatis mostly affects intensively farmed poultry birds causing loss in production with heavy mortality in broiler chicken and drop in egg production in layers with increased mortality [9]. Gallibacterium anatisis also reported to infect turkeys, geese, ducks, pheasants, partridges, budgerigars, peacock, cage birds, wild birds, cattle and pig [2,3,10-15]. Recently, it has also been associated with fatal bacteremia in immune-compromised patient [16]. Gallibacterium anatis causing disease in birds has been reported from all continents $[2,4,12,17,18]$. Its association with a variety of pathology makes it difficult to be diagnosed even after post-mortem in absence of pathgnomonic lesion(s) and the disease is often confused with Fowl Coryza, New Castle disease and Bird Flu [12].

Gallibacterium anatisis, a Gram-negative, rod shaped, non-motile, capsulated, facultative anaerobic bacteria was classified in family Pasteurellaceae by Pohl [11,12]. Gallibacterium anatis has two biovars i.e., a haemolytic biovar, Haemolytica and a non-haemolytic biovar, Anatis [12]. Currently, $G$. anatis and $G$. genomospecies 1, 2 [12], $G$. genomospecies 3 and Gallibacterium group V are the defined members of the genus Gallibacterium [11].

Though the infection of $G$. anatis is treatable with antibiotics, the frequency of treatment failure is an emerging and recurrent problem.
Multidrug resistant strains of $G$. anatis $[5,19]$ have shown resistance to sulpha drugs, novobiocin, tylosin, clindamycin, tetracycline and penicillin [20-28]. Concerns have been shown for biosecurity measures towards control of disease, handling of pathogen and prevention of spread. Gallibacterium should be handled at biosafety level 2 (BSL-2) facilities, it has a little potential personnel and environmental risk, and however, more is too understood for its exact categorisation to some risk group.

\section{Taxonomy of $G$. anatis}

It belongs to phylum, Proteobacteria; class, Gammaproteobacteria; family, Pasteurellaceae; genus, Gallibacterium and has two biovars, heamolytica and anatis [12,29]. First time in 1950 the bacteria was isolated from cloaca of healthy chickens and was described as haemolytic "cloaca bacterium" by Kjos-Hansen. The meaning of Gallibacterium is 'bacterium of chicken'. Being similar to Pasturella in several characters it was earlier known as $P$. anatis. The genus name Gallibacterium was first given by Bisgaard in the year 1982 on the basis of certain phenotypic characters used for identification of Actinobacillus salpingitidis and avian $P$. haemolytica $[2,10,11,30,31]$. Christensen et al. [32] established the genus Gallibacterium within the family of Pasteurellacae based on 16s rRNA gene sequences. The genus includes the strains belonging to $G$. anatis, $G$. genomospecies [1-3,12] and un-named group V [11]. Taxon 1 designated as a third group of strains, by Bisgaard in 1982 [30] and named Pasteurella anatis [29], was also found closely related to $A$. salpingitidis and avian $P$. haemolytica.

Besides this, comparison of whole genome by protein profiling [33] and amplified fragment length polymorphism [34] uncover the unique properties of five groups and assigned the proposal of new name to these three novel species of Gallibacterium naming, $G$. melopsittaci sp. nov. (Type strain F450T 5CCUG 36331T 5CCM 7538T), G. trehalosi fermentans sp. nov. (Type strain 52/S3/90T 5CCUG 55631T 5CCM 7539T) and G. salpingitidis sp. nov. (Type strain F150T 5CCUG 15564T 5CCUG 36325T 5NCTC 11414T). 
However, with DNA -DNA hybridization they could not be clubbed into one genus $[11,35]$. Confusion is still persistent in naming biovars and may be a continued debate in coming years.

\section{Epidemiology}

Gallibacterium have been reported from many European countries viz., Switzerland, Denmark, Germany, Austria [2,36-38], African countries viz., Nigeria [4], Asian countries including China, India and Japan [17], American countries viz., USA [18,39,40], and several other countries like Colombia, Taiwan, Norway, Australia, Syria, England Sweden and Czech Republic and recently in India. The epidemiological outcome strongly depends upon strain, route of inoculation and secondary factor [9]. Host and environmental factors have been observed to nurture the infection of $G$. anatis. Host factors playing a role are hormonal influences [41-43], age [2,44], stress [15], and compromised immunological status [45]. Important environmental factors are seasonal changes [23], and cold stress [46] in the similar pattern reported for infections with other members of Pasteurellaceae $[38,47,48]$.

\section{Habitat and host range}

Gallibacterium strains are known since long as common inhabitants of the respiratory tract and lower genital tract of healthy chickens $[2,10,49]$. Gallibacterium anatis has been isolated from chickens, ducks, geese, guinea fowl, turkeys, pheasants, psittacine birds, partridges, web-footed birds, cattle egrets and budgerigars $[3,10,49]$. Especially biovar haemolytica has also been isolated from healthy $[2,3,49,50]$ as well as sick birds, cattle and pigs [10-12,30,42,51].

\section{Cultural and biochemical characteristics}

The family Pasteurellaceae comprises large group of facultative anaerobes, gram-negative, non-sporing, chemo-organotrophic and fermentative bacteria including the genus Gallibacterium. All Gallibacterium species strains are non-motile have rod-shaped or pleomorphic cells occurring singly or in pairs. Colonies on bovine blood agar are strongly $\beta$-haemolytic, smooth, greyish, nontransparent, shiny and circular, raised, with entire margins, 1-2 mm diameter after $24-48 \mathrm{~h}$ at $37^{\circ} \mathrm{C}$, and glowing at the periphery having appearance of butyrous consistency [8,9]. All strains are catalase, oxidase, and phosphatase positive, and reduce nitrate [12]. Gallibacterium genus can be differentiated from other genera of Pasteurellaceae with catalase, symbiotic growth, hemolysis, urease, indole, acid production from (+) D-xylose, (-) D-mannitol, (-) Dsorbitol, (+) D-mannose, maltose, raffinose, dextrin, ONPG and PNPG tests [18].

\section{Transmission of $G$. anatis infection}

The common way of spreading infection is through horizontal dissemination. Infection of month old poultry birds common and appears to be natural [2]. Vertical transmission though not common in Pasteurellaceae family, trans-ovarian infection supporting the vertical transmission has been experimentally proved for $G$. anatis [52]. Isolation of $G$. anatis from the egg yolk and detection of $G$. anatis in a 4-day-old chicken descended from a diseased parent also supported vertical transmission hypothesis for the infection [43,45,53]. Ascending infections appears to be the most probable route for the infection of reproductive organs [38,50]. Venereal transmission of infections also seems to be feasible as the bacterium has been detected in semen of infected cockerels [54]. Under favourable circumstances, the bacterium can invade systemic circulation from its natural habitats in respiratory and reproductive tract $[38,39,55-57]$.

\section{Virulence factors}

RTX toxins are found in many members of Pasteurellaceae and are responsible for the haemolytic and leukotoxic properties in $G$. anatis [58]. Gallibacterium anatis biovar haemolytica produces haemolysin like GtxA which is a type of RTX-toxin [60]. GtxA induce a strong leukotoxic effect on avian macrophages and is labelled as a most important virulence factor of $G$. anatis $[7,43,59]$. GtxA toxin has two domains, C-terminal with homology to other RTX toxin and Nterminal with no homology. C-terminal is responsible for haemolytic function but function of $\mathrm{N}$-terminal is unknown, however, this domain is required for complete haemolytic activity [59]. The four operon genes are responsible for RTX toxin and are transcribed in an order i.e., $r t x C, r t x A, r t x B$, and $r t x D$ [43]. MARTX (multifunctional autoprocessing RTX) toxins bind and regulate the actin protein of cytoskeleton by which microorganism making a path of immune evasion strategy [60].

Gallibacterium anatis have capability to adhere on the epithelial cells of chicken and other host cells [61,62] by short fimbriae [63]. A number of fimbriae of different sizes and shapes have been defined belonging to the F17-like fimbriae and are grouped in 1-3 different fimbrial cluster [64]. The flfG gene cluster is responsible for adhesion protein of F17 family [65]. One of the detected fimbriae seems to be type IV-like pili having bundle structure formed by thin filament like other pathogenic microorganisms evincing type IV pili [66]. Type IV fimbriae are appendages participating in intercellular motility, microcolony formation, colonization, and the secretion of proteases by host tissues [67].

Gallibacterium anatis produces outer membrane vesicles (OMVs) in vitro [65] similar all other Gram-negative bacteria. Virulence properties of OMVs shown by microorganism are adherence, colonization, binding and removal of antibacterial substances along with antibiotics which envisage the survival of microorganism $[68,69]$. Beside, periplasmic components, compounds of cytoplasmic origin such as DNA have also been found as components contents in OMVs $[69,70]$.

Gallibacterium have capsule in some strain which may contain virulence properties as seen in Pasteurella multocida [71]. Capsule is a general structure made up of extracellular polysaccharide and has been reported in both Gram-negative and Gram-positive pathogens [72]. The presence of a thin capsule on $G$. anatis has been observed by transmission electron microscopy [73]. The presence of a capsule in primary culture and disappearance after sub-culture is common finding [14].

Gallibacterium anatis metalloproteases may be having role in infection process [74] are extracellular Zn containing enzymes [74-76], however, their exact role is still to be understood.

Ability of a bacterium to form biofilm indicates its ability of adherence to surfaces and live tissues and plays role in pathogenesis of persistent and chronic infections with increased resistance to antimicrobials $[77,78]$. Biofilm forming ability varies between isolates of $G$. anatis and categorises as weak, moderate and strong biofilm producer [79]. 
Some strains of $G$. anatis agglutinate avian erythrocytes [80,81]. The presence of a potential haemagglutinin in OMVs released from $G$. anatis has been observed [79,82]. The activity of haemagglutinating (HAs) to RBC of host are of mainly depend on two type adhesins naming filamentous adhesins and non-filamentous adhesins of pathogens [83]. The type identity of adhesins of $G$. anatis involve in HAs are still unknown [81]. Some of these haemagglutinins could be responsible for the observed agglutinating activity of some strains [79,82-84].

Clustered regularly interspaced short palindromic repeats (CRISPRs) consider as a defence system of bacteria against foreign invasive DNA, such as DNA from phages and plasmids. The difference of natural competence have been explicate between strains of $G$. anatis by CRISPRs interfere in the process of transformation $[85,86]$.

Integrative conjugative elements (ICE) have genes which are present within these elements are capable to excise and integrate in the genome [87]. Identification of ICEs have been reported in the genomes of $G$. anatis [79]. As we know that antimicrobial resistance have been reported in the large number of isolates of $G$. anatis with the possibilities of association to ICEs [19]. Genes encoding fimbrial clusters (flf) have been reported with adjacent mobile elements [64].

Small colony variants (SCVs) have been observed with differences of haemolytic activity [88], in primary cultures of Gallibacterium $[45,88,89]$. Increased persistence, recurrent infections and increased resistance towards antimicrobials have been observed in association with SCVs [8].

\section{Pathogenesis}

Repeated isolation of $G$. anatis from the trachea and cloaca of healthy birds indicates its commensal status in the upper respiratory tract and lower genital tract of healthy chickens [2,14,49,50,55,90]. However, isolation of $G$. anatis in association with a wide range of different pathological lesions, including septicaemia, pericarditis, hepatitis, oophoritis, follicle degeneration, enteritis, upper respiratory tract lesions, salpingitis and peritonitis revealed its importance as an opportunistic pathogen [2,17,36,39-43,45,47,55,88,89,91,92]. Recent investigations confirmed that $G$. anatis colonizes the upper respiratory tract without causing clinical signs, whereas it may cause severe lesions in the reproductive tract $[54,56]$. Studies established $G$. anatis as the most common single bacterial infection in chickens causing reproductive tract disorders [36]. Simultaneous infection with other microorganisms $[39,47,48]$, hormonal influences $[42,43]$, age $[2,45]$, seasonal changes [36], stress [15], cold stress [47], and compromised immunological status [46] are a few predisposing factors nurturing the infection of $G$. anatis. In experimental infections semen quality has been found to be reduced significantly due to decrease in sperm density, total motility with progressive motility, and membrane integrity [54].

\section{Disease associated with $\boldsymbol{G}$. anatis infection}

Due to vast range of pathological manifestations of $G$. anatis infection it is difficult to decide the exact disease condition caused by $G$. anatis. Incidences of infection to chicken increase during the peak and late phases of production period [41]. In diseased birds' mortality might take place mainly due to salpingitis, oophoritis and peritonitis. Respiratory tract infections might be responsible for major economic losses due to the rise in treatment cost and losses due to higher condemnation rates and mortality.
Gallibacterium may be causing primary or secondary infections leading to fatal bacteremia, septicaemia and acute septicaemia [41]. The severity of clinical signs, duration of the disease and mortality rate are variable and influenced by environmental factors, such as poor hygiene, inadequate management ventilation, ammonia levels in poultry premises and concurrent diseases. Study on pathogen-specific genes of Gallibacterium populations [79] suggested the ability of the pathogen to cause lesions in reproductive organs such as folliculitis, ruptured and haemorrhagic follicles as well as a drop in egg production in adult hens $[22,38,55,90]$. Haemolytic $G$. anatis was associated with infection in birds kept in alternative husbandry systems and suffering from reproductive disorders [38].

\section{Clinical sign and lesion on $G$. anatis infection}

Normally the signs and symptom of diseases caused by $G$. anatis infection in chicken are not pathgnomonic leading to creation of confusion between the different similar symptomatic disease like Newcastle, fowl cholera and bird flu. The clinical sign are unspecific but include depression, diarrhoea, pasting around the vent and loss of egg production take place around peak of lay [41]. Mirle et al. [36] examined 496 hens with reproductive tract lesions and isolated Gallibacterium in pure culture from 23\% of the diseased organs. Even though haemolytic isolates are primarily diseased causing biovar but non-haemolytic strains might be associated with chronic cases of localized or generalized purulent peritonitis with $E$. coli [41].

\section{Diagnosis of Gallibacterium infection}

Gallibacterium anatis infection can be confirmed only through agent isolation characterised by phenotypic and genotypic methods. The difference between the genomospecies 1 and 2 is possible only through genotypic methods due to the phenotypic heterogeneity among strains [12]. Presently the best way to identify the Gallibacterium is its phenotypic (Table 1) characterisation [12] or with GAN850, a $G$. anatis specific probeat position between 850-867 of $16 \mathrm{~S}$ rRNA [93]. A number of genotypic methods have been established for identification of Gallibacterium [12,18,49]. The specificity of these methods, however, remains to be investigated [11]. Gallibacterium has a relatively short internal transcribed $16 \mathrm{~S}$ to $23 \mathrm{~S}$ rRNA gene sequences compared to other members of Pasteurellaceae, based on the information the Gallibacterium specific PCR [18] targeting on 16s rRNA sequence are designed [94]. These Specific ITS-PCR able to amplifies selectively Gallibacterium DNA and generating short fragments compared to other members of Pasteurellaceae [95-97]. Primers chosen with specificity for $G$. anatis are 1133 fgal ( $5^{\circ}$ TATTCTTTGTTACCARCGG-3') and $114 \mathrm{r}$ (5'GGTTTCCCCATTCGG-3') [18,98]. Besides this, AFLP typing method and pulsed-field gel electrophoresis are found to be useful for distinguishing between closely related $G$. anatis clones, thus enabling recognition of specific pathogenic clonal lineages [99-101].

Rapid and specific identification of individual bacterial cells can be achieved by the fluorescent in situ hybridization technique (FISH), based on fluorescent labelled oligonucleotides complementary to bacterial 16S rRNA. This method has advantages over the traditional culture based methods due to its ability to identify live/intact cells as well as non-cultivable organisms [49]. Rapid and accurate identification of related organism can be made along with $G$. anatis in human being with help of gene identified like soda gene [102]. 
Serological studies also have been found to be helpful in detection of $G$. anatis specific antibodies in infected tested sera by latex agglutination test and enzyme-linked immunosorbent assay (ELISA) [41].

\begin{tabular}{|l|l|l|l|l|l|l|}
\hline Characteristics & $\begin{array}{l}\text { G. anatis biovar } \\
\text { haemolytica }\end{array}$ & $\begin{array}{l}\text { G. anatis } \\
\text { biovar } \\
\text { anatis }\end{array}$ & G. genomospecies 1 & G. genomospecies 2 & G. genomospecies 3 \\
\hline B-Haemolysis & + & - & + & + & - \\
\hline Production of acid from: & $(+)$ & - & $(+)$ & D & D (+/-) \\
\hline$(-)$ D- Arabinose & - & - & D & D & D (+/-) \\
\hline$(+)$ L- Arabinose & + & D & D & \\
\hline Mannitol & D & D & - & D & D (+/-) \\
\hline m-Inositol & D & (+) & D & - & - & D (+/-) \\
\hline (-) D- Sorbitol & D & - & $+/(+)$ & D & ( \\
\hline (-) L- Fucose & D & - & + & + & - \\
\hline Maltose & D & + & - & $+/(+)$ & D & - \\
\hline Trehalose & & & + & \\
\hline Dextrin & & & \\
\hline
\end{tabular}

Table 1: Phenotypic characters of Gallibacterium species [12]. Note: Characters are scored as:,$+ \geq 90 \%$ of strains positive within $1-2$ days; $(+)$, $\geq$ $90 \%$ of strains positive within 3-14 days; -, <10\% of strains positive within 14 days; d, $11-89 \%$ of strains positive, $D$, doubt (+/-) variation from strain to strain.

\section{Prevention and control of $G$. anatis infection}

A pan-genomic reverse vaccinology (RV) approach has been applied to identify novel and potentially broadly protective immunogens from $G$. anatis [84,103-105]. Screening approaches of reverse vaccinology have been applied to identify potential immunogens for 71 proteins in which only one protein contain immunization properties [106]. FlfA and GtxA-N have potential to induce a protective immunity in the homologous strain of $G$. anatis [83]. Although, some commercial vaccine are available for more prevalent three biovar [40] but there is no potential vaccine globally present in the market to control G. anatis infection and still protection under field condition remains to be investigated against commercial vaccine [40]. Only antimicrobial chemotherapy is the available method for containment of the disease caused by $G$. anatis, however, it is also proven that $G$. anatis rapidly acquires resistance [40]. Besides, general hygienic measures can be taken in the way similar to control of other contagious diseases in poultry farms.

\section{Antimicrobial drug resistance in Gallibaterium}

Emergence of antimicrobial resistance has been observed among several organisms belonging to the Pasteurellaceae family $[5,106]$ including $G$. anatis isolates. Though the infection of Gallibacterium is treatable with antibiotics, the frequency of treatment failure of Gallibacterium seems to be a recurrent problem [107,108]. Resistance in chicken origin isolates of Gallibacterium is documented to novobiocin, tylosin, clindamycin, spectinomycin, tetracycline antimicrobials and penicillin [20-26,52,109]. In contrast, Berge et al. reported rarity of tetracycline resistance in $G$. anatis of sheep and goat origin [27].

\section{Conclusions}

Gallibacterium anatis especially biovar haemolytica has emerged as an important pathogen of broilers and layers in several countries. However, in lack of elaborate scientific understanding of the pathogen and vaccine(s), efforts to control outbreaks and prevent the disease is a big challenge for poultry scientists and microbiologists.

\section{References}

1. AVEC (2014) Association of Poultry Processors and Poultry Trade in the EU Countries -ASBL Annual Report, Rue du Luxembourg, Belgium.

2. Bisgaard M (1977) Incidence of Pasteurella haemolytica in the respiratory tract of apparently healthy chickens and chickens with infectious bronchitis. Characterization of 213 strains. Avian Patho 16: 285-292.

3. Mushin R, Weisman Y, Singer N (1980) Pasteurella haemolytica found in the respiratory tract of fowl. Avian Dis 24: 162-168.

4. Addo PB, Mohan K (1985) Atypical Pasteurella haemolytica type A from poultry. Avian Dis 29: 214-217.

5. Aarestrup FM, Seyfarth AM, Angen $\varnothing$ (2004) Antimicrobial susceptibility of Haemophilus parasuis and Histophilus somni from pigs and cattle in Denmark. Vet Microbiol 101: 143-146.

6. Jordan FT, Williams NJ, Wattret A, Jones T (2005) Observations on salpingitis, peritonitis and salpingoperitonitis in a layer breeder flock. Vet Rec 157: 573-577.

7. Kristensen BM, Frees D, Bojesen AM (2011) Expression and secretion of the RTX-toxin GtxA among members of the genus Gallibacterium. Vet Microbiol 153: 116-123.

8. Proctor RA, von Eiff C, Kahl BC, Becker K, McNamara P, et al. (2006) Small colony variants: a pathogenic form of bacteria that facilitates persistent and recurrent infections. Nat Rev Microbiol 4: 295-305.

9. BojesenAM, Christensen JP, Bisgaard M (2008) Gallibacterium infections and other avian Pasteurellaceae. In: Pattison M, McMullin PF, Bradbury 
JM, Alexander DJ (eds.) Poultry Diseases (6th edn.), Philadephia, Saunders Elsevier pp: 160-163.

10. Bisgaard M (1993) Ecology and significance of Pasteurellaceae in animals. Zentralbl Bakteriol 279: 7-26.

11. Bisgaard M, Korczak BM, Busse HJ, Kuhnert P, Bojesen AM, et al. (2009) Classification of the taxon 2 and taxon 3 complex of Bisgaard within Gallibacterium and description of Gallibacterium melopsittaci sp. nov., Gallibacterium trehalosifermentans sp. nov. and Gallibacterium salpingitidis sp. nov. Int J Syst Evol Microbiol 59: 735-744.

12. Christensen H, Bisgaard M, Bojesen AM, Mutters R, Olsen JE (2003) Genetic relationships among avian isolates classified as Pasteurella haemolytica, 'Actinobacillus salpingitidis' or Pasteurella anatis with proposal of Gallibacterium anatis gen. nov., comb. nov. and description of additional genomospecies within Gallibacterium gen. nov. Int J Syst Evol Microbiol 53: 275-287.

13. Gregersen RH, Neubauer C, Christensen H, Korczak B, Bojesen AM, et al. (2010) Characterization of Pasteurellaceae-like bacteria isolated from clinically affected psittacine birds. J Appl Microbiol 108: 1235-1243.

14. Kjos-Hanssen B (1950) Egg peritonitis in hens caused by pathogenic cloacal bacteria. Nordisk Vet Med 2: 523-531.

15. Rzewuska M, Karpinska E, Szeleszczuk P, Binek M (2007) Isolation of Gallibacterium spp. from peacocks with respiratory tract infections. Medycyna Wet 63: 1431-1433.

16. Aubin GG, Haloun A, Treilhaud M, Reynaud A, Corvec S (2013) Gallibacterium anatis bacteremia in a human. J Clin Microbiol 51: 3897-3899.

17. Suzuki T, Ikeda A, Shimada J, Yanagawa Y, Nakazawa M, et al. (1996) Isolation of Actinobacillus salpingitidis/ avian Pasteurella haemolyticalike organisms group from diseased chickens. JVMA (Japan) 49: 800-809.

18. Bojesen AM, Vazquez ME, Robles F, Gonzalez C, Soriano EV, et al. (2007) Specific identification of Gallibacterium by a PCR using primers targeting the 16S rRNA and 23S rRNA genes. Vet Microbiol 123: 262-268.

19. Bojesen AM, Vazquez ME, Bager RJ, Ifrah D, Gonzalez C, et al. (2011) Antimicrobial susceptibility and tetracycline resistance determinant genotyping of Gallibacterium anatis. Vet Microbiol 148: 105-110.

20. Hendriksen RS, Mevius DJ, Schroeter A, Teale C, Meunier D, et al. (2008) Prevalence of antimicrobial resistance among bacterial pathogens isolated from cattle in different European countries: 2002-2004. Acta Vet Scand 50: 28 .

21. Johnson TJ, Fernandez-Alarcon C, Bojesen AM, Nolan LK, Trampel DW, et al. (2011) Complete genome sequence of Gallibacterium anatis strain UMN179, isolated from a laying hen with peritonitis. J Bacteriol 193: 3676-3677.

22. Jones KH, Thornton JK, Zhang Y, Mauel MJ (2013) A 5-year retrospective report of Gallibacterium anatis and Pasteurella multocida isolates from chickens in Mississippi. Poult Sci 92: 3166-3171.

23. Malik Y, Chander Y, Gupta S, Goyal S (2005) A retrospective study on antimicrobial resistance in Mannheimia (Pasteurella) haemolytica, Escherichia coli, Salmonella species, and Bordetella avium from chickens in Minnesota. J Appl Poult Res 14: 506-511.

24. Post KW, Cole NA, Raleigh RH (1991) In vitro antimicrobial susceptibility of Pasteurella haemolytica and Pasteurella multocida recovered from cattle with bovine respiratory disease complex. J Vet Diagn Invest 3: 124-126.

25. Watts JL, Yancey RJ Jr, Salmon SA, Case CA (1994) A 4-year survey of antimicrobial susceptibility trends for isolates from cattle with bovine respiratory disease in North America. J Clin Microbiol 32: 725-731.

26. Mevius DJ, Hartman EG (2000) In vitro activity of 12 antibiotics used in veterinary medicine against Mannheimia haemolytica and Pasteurella multocida isolated from calves in the Netherlands. Tijdschr Diergeneeskd 125: 147-152.

27. Berge AC, Sischo WM, Craigmill AL (2006) Antimicrobial susceptibility patterns of respiratory tract pathogens from sheep and goats. J Am Vet Med Assoc 229: 1279-1281.
28. Guo L, Wang C, Yang X, Chen L, Zheng L, et al. (2009) Study of relation between drug resistance against sulfamethoxazole and streptomycin in Gallibacterium and resistant genes. China Poultry 18: 008.

29. Mutters R, Ihm P, Pohl S, Frederiksen W, Mannheim W (1985) Reclassification of the genus Pasteurella Trevisan 1887 on the basis of deoxyribonucleic acid homology, with proposals for the new species Pasteurella dagmatis, Pasteurella canis, Pasteurella stomatis, Pasteurella anatis, and Pasteurella langaa. Int J Syst Evol Microbiol 35: 309-322.

30. Bisgaard M (1982) Isolation and characterization of some previously unreported taxa from poultry with phenotypical characters related to Actinobacillus and Pasteurella species. Acta Pathol Microbiol Scand B: Microbiol 90: 59-67.

31. Nicolet J, Fey H (1965) Role of Pasteurella haemolytica in Salpingitis of fowl. Schweiz Arch Tierheilkd 107: 329-334.

32. Christensen H, Foster G, Christensen JP, Pennycott T, Olsen JE, et al. (2003) Phylogenetic analysis by $16 \mathrm{~S}$ rDNA gene sequence comparison of avian taxa of Bisgaard and characterization and description of two new taxa of Pasteurellaceae. J Appl Microbiol 95: 354-363.

33. Bisgaard M, Brown DJ, Costas M, Ganner M (1993) Whole cell protein profiling of actinobacillus-like strains classified as taxon 2 and taxon 3 according to Bisgaard. Zentralbl Bakteriol 279: 92-103.

34. Bojesen AM, Christensen H, Nielsen SS, Bisgaard M (2007) Host-specific bacterial lineages in the taxon 2 and 3 complex of Pasteurellaceae. Syst Appl Microbiol 30: 119-127.

35. Piechulla K, Bisgaard M, Gerlach H, Mannheim W (1985) Taxonomy of some recently described avian Pasteurella/Actinobacillus-like organisms as indicated by deoxyribonucleic acid relatedness. Avian Pathol 14: 281-311.

36. Mirle C, Schöngarth M, Meinhart H, Olm U (1991) Studies into incidence of Pasteurella haemolytica infections and their relevance to hens, with particular reference to diseases of the egg-laying apparatus. Monatshefte fuer Vet Med (Germany, FR) 46: 545-549.

37. Mráz O, Vladík P, Bohácek J (1976) Actinobacilli in domestic fowl. Zentralbl Bakteriol Orig A 236: 294-307.

38. Neubauer C, De Souza-Pilz M, Bojesen AM, Bisgaard M, Hess M (2009) Tissue distribution of haemolytic Gallibacterium anatis isolates in laying birds with reproductive disorders. Avian Pathol 38: 1-7.

39. Shaw DP, Cook DB, Maheswaran SK, Lindeman CJ, Halvorson DA (1990) Pasteurella haemolytica as a co-pathogen in pullets and laying hens. Avian Dis 34: 1005-1008.

40. Mendoza K, Zavaleta AI, KogaY, Rodriguez J, Alvarado A, et al. (2014) Genetic variability of strains isolated from commercial Gallibacterium anatis birds of Peru with respiratory infections. J Vet Res Peru 25: 233-244.

41. Gerlach H (1977) The significance of Pasteurella haemolytica in poultry. Prakt Tierartz. 58: 324-328.

42. Persson G, BojesenAM (2015) Bacterial determinants of importance in the virulence of Gallibacterium anatis in poultry. Vet Res 46: 57.

43. Kohlert R (1968) Studies on the etiology of inflammation of the oviduct in the hen. Monatsh Veterinarmed 23: 392-395.

44. Janetschke P, Risk G (1970) Frequent occurrence of Pasteurella hemolytica in the domestic chicken in Syria. Monatsh Veterinarmed 25: 23-27.

45. Bojesen AM, Nielsen OL, Christensen JP, Bisgaard M (2004) In vivo studies of Gallibacterium anatis infection in chickens. Avian Pathol 33: 145-152.

46. Matthes S, Löliger HC (1976) Kinetics of bacterial infections in hens. Berl Munch Tierarztl Wochenschr 89: 98-102.

47. Gilchrist P (1963) A survey of avian respiratory diseases. Australian Vet J 39: $140-144$

48. Matthes S, Löliger HC, Schubert HJ (1969) Enzootic in chicken due to pasteurella haemolytica. Dtsch Tierarztl Wochenschr 76: 88-95.

49. Bojesen AM, Nielsen SS, Bisgaard M (2003) Prevalence and transmission of haemolytic Gallibacterium species in chicken production systems with different biosecurity levels. Avian Pathol 32: 503-510. 
50. Harry E (1962) A haemolytic coccobacillus recovered from poultry. Vet Rec 74: 640.

51. Lin MY, Lin KJ, Lan YC, Liaw MF, Tung MC (2001) Pathogenicity and drug susceptibility of the Pasteurella anatis isolated in chickens in Taiwan. Avian Dis 45: 655-658.

52. Matthes S, Hanschke J (1977) Experimental studies on bacteria transmission via chicken egg. Berl Munch Tierarztl Wochenschr 90: 200-203.

53. Shapiro J, Brash M, Martin E, BrooksA, Slavic D, et al. (2013) Gallibacterium anatis: A review of culture-positive cases from commercial poultry submitted to the AHL in 2011 and 2012. AHL Newsletter 17: 1-6.

54. Paudel S, Liebhart D, Aurich C, Hess M, Hess C (2014) Pathogenesis of Gallibacterium anatis in a natural infection model fulfils Koch's postulates: 2. Epididymitis and decreased semen quality are the predominant effects in specific pathogen free cockerels. Avian Pathol 43: 529-534.

55. Hacking WC, Pettit JR (1974) Pasteurella hemolytica in pullets and laying hens. Avian Dis 18: 483-486.

56. Paudel S, Alispahic M, Liebhart D, Hess M, Hess C (2013) Assessing pathogenicity of Gallibacterium anatis in a natural infection model: the respiratory and reproductive tracts of chickens are targets for bacterial colonization. Avian Pathol 42: 527-535.

57. Zepeda VA, Calderón-Apodaca NL, Paasch ML, Martín PG, Paredes DA et al. (2010) Histopathologic findings in chickens experimentally infected with Gallibacterium anatis by nasal instillation. Avian Dis 54: 1306-1309.

58. Frey J, Kuhnert P (2002) RTX toxins in Pasteurellaceae. Int J Med Microbiol 292: 149-158.

59. Kristensen BM, Frees D, Bojesen AM (2010) GtxA from Gallibacterium anatis, a cytolytic RTX-toxin with a novel domain organisation. Vet Res 41: 25 .

60. Aktories K, Lang AE, Schwan C, Mannherz HG (2011) Actin as target for modification by bacterial protein toxins. FEBS J 278: 4526-4543.

61. Klemm P, Schembri MA (2000) Bacterial adhesins: function and structure. Int J Med Microbiol 290: 27-35.

62. Lucio MLS, Vaca S, Vázquez C, Zenteno E, Rea I, et al. (2012) Adhesion of Gallibacterium anatis to chicken oropharyngeal epithelial cells and the identification of putative fimbriae. Adv Microbiol 2: 505-510.

63. Vaca S, Monroy E, Rojas L (2011) Adherence of Gallibacterium anatis to inert surfaces. J Anim Vet Adv 10: 1688-1693.

64. KudirkienÄ-E, Bager RJ, Johnson TJ, Bojesen AM (2014) Chaperoneusher fimbriae in a diverse selection of Gallibacterium genomes. BMC Genomics 15: 1093.

65. Bager RJ, Nesta B, Pors SE, Soriani M, Serino L, et al. (2013) The fimbrial protein FlfA from Gallibacterium anatis is a virulence factor and vaccine candidate. Infect Immun 81: 1964-1973.

66. Craig L, Pique ME, Tainer JA (2004) Type IV pilus structure and bacterial pathogenicity. Nat Rev Microbiol 2: 363-378.

67. Craig L, Li J (2008) Type IV pili: paradoxes in form and function. Curr Opin Struct Biol 18: 267-277.

68. Kulp A, Kuehn MJ (2010) Biological functions and biogenesis of secreted bacterial outer membrane vesicles. Annu Rev Microbiol 64: 163-184.

69. MacDonald IA, Kuehn MJ (2012) Offense and defense: microbial membrane vesicles play both ways. Res Microbiol 163: 607-618.

70. Mashburn-Warren LM, Whiteley M (2006) Special delivery: vesicle trafficking in prokaryotes. Mol Microbiol 61: 839-846.

71. Boyce JD, Adler B (2000) The capsule is a virulence determinant in the pathogenesis of Pasteurella multocida M1404 (B:2). Infect Immun 68: 3463-3468.

72. Willis LM, Whitfield C (2013) Structure, biosynthesis, and function of bacterial capsular polysaccharides synthesized by $\mathrm{ABC}$ transporterdependent pathways. Carbohydr Res 378: 35-44.

73. Bojesen AM, Kristensen BM, Pors SE (2011) The role of the capsule in the pathogenesis of Gallibacterium anatis in chickens. In: (eds.) International Pasteurellaceae Conference (IPC), Elsinore.
74. García-Gómez E, Vaca S, Pérez-Méndez A, Ibarra-Caballero J, PérezMárquez V, et al. (2005) Gallibacterium anatis-secreted metalloproteases degrade chicken IgG. Avian Pathol 34: 426-429.

75. Häse CC, Finkelstein RA (1993) Bacterial extracellular zinc-containing metalloproteases. Microbiol Rev 57: 823-837.

76. Miyoshi S, Shinoda S (2000) Microbial metalloproteases and pathogenesis. Microbes Infect 2: 91-98.

77. Costerton JW, Stewart PS, Greenberg EP (1999) Bacterial biofilms: a common cause of persistent infections. Science 284: 1318-1322.

78. Donlan RM, Costerton JW (2002) Biofilms: survival mechanisms of clinically relevant microorganisms. Clin Microbiol Rev 15: 167-193.

79. Johnson TJ, Danzeisen JL, Trampel D, Nolan LK, Seemann T, et al. (2013) Genome analysis and phylogenetic relatedness of Gallibacterium anatis strains from poultry. PLoS One 8: e54844.

80. Ramirez-Apolinar S, Guerra-Infante FM, Haro-Cruz MdJd, SalgadoMiranda C, Madrid-Morales E, et al. (2012) Characterization of a Gallibacterium genomospecies 2 hemagglutinin. J Anim Vet Adv 11: 556-560.

81. Zepeda A, Ramírez S, Vega V, Morales V, Talavera M, et al. (2009) Hemagglutinating activity of Gallibacterium strains. Avian Dis 53: 115-118.

82. Bager RJ, Persson G, Nesta B, Soriani M, Serino L, et al. (2013) Outer membrane vesicles reflect environmental cues in Gallibacterium anatis. Vet Microbiol 167: 565-572.

83. Pedersen IJ, Pors SE, Bager Skjerning RJ, Nielsen SS, Bojesen AM (2015) Immunogenic and protective efficacy of recombinant protein GtxA-N against Gallibacterium anatis challenge in chickens. Avian Pathol 44: 386-391.

84. Bager RJ, Kudirkiene E, da Piedade I, Seemann T, Nielsen TK, et al. (2014) In silico prediction of Gallibacterium anatis pan-immunogens. Vet Res 45: 80 .

85. Horvath P, Barrangou R (2010) CRISPR/Cas, the immune system of bacteria and archaea. Science 327: 167-170.

86. Kristensen BM, Sinha S, Boyce JD, Bojesen AM, Mell JC, et al. (2012) Natural transformation of Gallibacterium anatis. Appl Environ Microbiol 78: 4914-4922.

87. Wozniak RA, Fouts DE, Spagnoletti M, Colombo MM, Ceccarelli D, et al. (2009) Comparative ICE genomics: insights into the evolution of the SXT/R391 family of ICEs. PLoS Genet 5: e1000786.

88. Greenham L, Hill T (1962) Observations on an avian strain of Pasteurella haemolytica. Vet Rec 74: 861-863.

89. Harbourne J, Watson W, Association BV (1962) A haemolyticcoccobacillus recovered from poultry. J British Vet Assoc 74: 566-567.

90. Paudel S, Liebhart D, Hess M, Hess C (2014) Pathogenesis of Gallibacterium anatis in a natural infection model fulfils Koch's postulates: 1. Folliculitis and drop in egg production are the predominant effects in specific pathogen free layers. Avian Pathol 43: 443-449.

91. Hinz K (1970) BakteriologischeBefundebeiErkrankung der Atmungsorgane von Junghennen. World Vet Poultry Ass Int Congr 4: 713-715.

92. Majid MS, Ideris A, Aziz AR (1986) Isolation of Pasteurella haemolytica from the spleen of chickens. Pertanika 9: 265-266.

93. Bojesen AM, Christensen H, Nielsen OL, Olsen JE, Bisgaard M (2003) Detection of Gallibacterium spp. in chickens by fluorescent $16 \mathrm{~S}$ rRNA in situ hybridization. J Clin Microbiol 41: 5167-5172.

94. Benson DA, Karsch-Mizrachi I, Lipman DJ, Ostell J, Wheeler DL (2004) GenBank: update. Nucleic Acids Res 32: 23-26.

95. Fussing V, Paster BJ, Dewhirst FE, Poulsen LK (1998) Differentiation of Actinobacillus pleuropneumoniae strains by sequence analysis of $16 \mathrm{~S}$ rDNA and ribosomal inter genic regions, and development of a species specific oligonucleotide for in situ detection. Syst Appl Microbiol 21: 408-418.

96. Leys EJ, Griffen AL, Strong SJ, Fuerst PA (1994) Detection and strain identification of Actinobacillus actinomycetemcomitans by nested PCR. J Clin Microbiol 32: 1288-1294. 
Citation: $\quad$ Singh SV, Singh BR, Sinha DK, Kumar VOR, Vadhana PA, et al. (2016) Gallibacterium anatis: An Emerging Pathogen of Poultry Birds and Domiciled Birds. J Veterinar Sci Techno 7: 324. doi:10.4172/2157-7579.1000324

Page 7 of 7

97. Gu XX, Rossau R, Jannes G, Ballard R, Laga M, et al. (1998) The rrs (16S)-rrl (23S) ribosomal intergenic spacer region as a target for the detection of Haemophilus ducreyi by a heminested-PCR assay. Microbiology 144 : 1013-1019.

98. Lane DJ (1991) 16S/23S rRNA sequencing. In: Stackebrandt E, Goodfellow M, editors. Nucleic acid techniques in bacterial systematics. Chichester, United Kingdom: John Wiley and Sons pp. 115-175.

99. Bojesen AM, Torpdahl M, Christensen H, Olsen JE, Bisgaard M (2003) Genetic diversity of Gallibacterium anatis isolates from different chicken flocks. J Clin Microbiol 41: 2737-2740.

100. Spratt BG, Maiden MC (1999) Bacterial population genetics, evolution and epidemiology. Philos Trans R Soc Lond B Biol Sci 354: 701-710.

101. Vos P, Hogers R, Bleeker M, Reijans M, van de Lee T, et al. (1995) AFLP: a new technique for DNA fingerprinting. Nucleic Acids Res 23: 4407-4414.

102. Gautier AL, Dubois D, Escande F, Avril JL, Trieu-Cuot P, et al. (2005) Rapid and accurate identification of human isolates of Pasteurella and related species by sequencing the sodA gene. J Clin Microbiol 43: 2307-2314.

103. Medini D, Donati C, Tettelin H, Masignani V, Rappuoli R (2005) The microbial pan-genome. Curr Opin Genet Dev 15: 589-594.
104. Rappuoli R (2001) Reverse vaccinology, a genome-based approach to vaccine development. Vaccine 19: 2688-2691.

105. Hatfaludi T, Al-Hasani K, Gong L, Boyce JD, Ford M, et al. (2012) Screening of $71 \mathrm{P}$. multocida proteins for protective efficacy in a fowl cholera infection model and characterization of the protective antigen PlpE. PLoS One 7: e39973.

106. Aarestrup FM (2005) Veterinary drug usage and antimicrobial resistance in bacteria of animal origin. Basic Clin Pharmacol Toxicol 96: 271-281.

107. Kehrenberg C, Walker R, Wu C, Schwarz S (2006) Antimicrobial resistance in members of the family Pasteurellaceae. Antimicrobial resistance in bacteria of animal origin ASM Press, Washington, DC 167-186.

108. Bortolaia V, Guardabassi L, Bisgaard M, Larsen J, Bojesen AM (2010) Escherichia coli producing CTX-M-1, -2, and -9 group beta-lactamases in organic chicken egg production. Antimicrob Agents Chemother 54: 3527-3528.

109. Schwarz S, Kehrenberg C, Salmon SA, Watts JL (2004) In vitro activities of spectinomycin and comparator agents against Pasteurella multocida and Mannheimia haemolytica from respiratory tract infections of cattle. J Antimicrob Chemother 53: 379-382. 